The influence of digestate concentration during cultivation on the quality of biogas obtained from the anaerobic digestion of duckweed (Spirodela polyrhiza)

Utjecaj koncentracije digestata prilikom uzgoja na kvalitetu bioplina dobivenoga anaerobnom digestacijom vodene leće (Spirodela polyrhiza)

Matošević, D., Kralik, D., Rapčan, I., Jovičić, D.

Poljoprivreda/Agriculture

ISSN: 1848-8080 (Online)

ISSN: 1330-7142 (Print)

http://dx.doi.org/10.18047/poljo.25.2.10

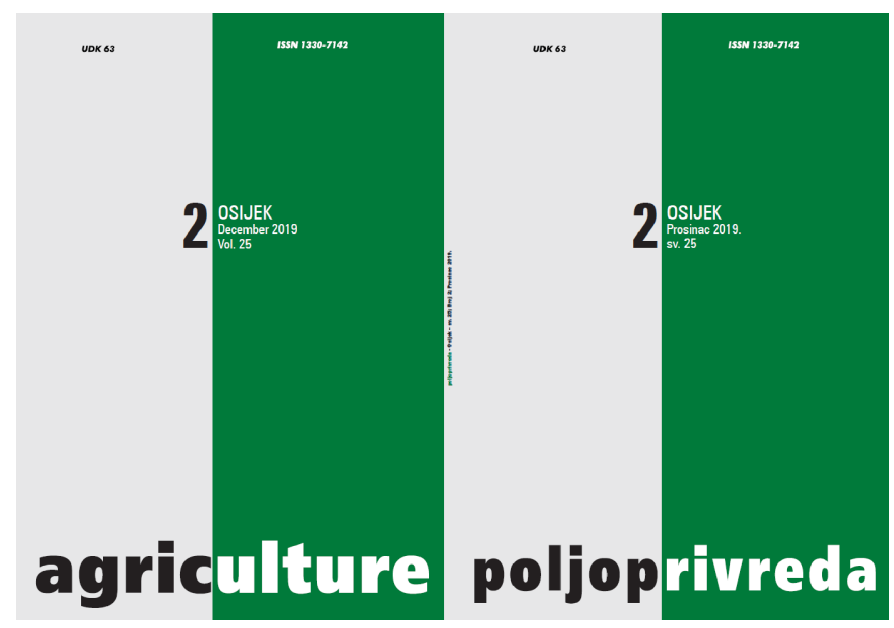

Fakultet agrobiotehničkih znanosti Osijek, Poljoprivredni institut Osijek

Faculty of Agrobiotechnical Sciences Osijek, Agricultural Institute Osijek 


\title{
THE INFLUENCE OF DIGESTATE CONCENTRATION DURING CULTIVATION ON THE QUALITY OF BIOGAS OBTAINED FROM THE ANAEROBIC DIGESTION OF DUCKWEED (Spirodela polyrhiza)
}

\author{
Matošević, D. ${ }^{(1)}$, Kralik, D. ${ }^{(2)}$, Rapčan, $I^{(2)}$, Jovičić, $D^{(2)}$
}

\begin{abstract}
SUMMARY
Duckweed is a widespread type of tiny free-floating plants of the flowering class. A typical representative of the family of the cowhide (Lemnaceae) is a large duckweed (Spirodela polyrhiza) and it is very common on Croatian inland waters. Like all other species of duckweeds, it is characterized by the possibility of vegetative and sexual reproduction and very rapid growth. It has the ability to remove nitrogen, phosphorus and some heavy metals from the substrate and is considered a very desirable raw material for biogas production for several reasons. The necessity of reducing environmental pollution of nitrates from agricultural production and the ability to grow water lenses under eutrophic conditions have sparked this research. The primary objective of the study is to determine the possibilities of continuously growing large duckweed at different concentrations of digestates for the purpose of biogas production. The secondary goal is to determine the dependence between the different digestate concentrations used for the duckweed green mass production and the quantity and quality of the biogas obtained through the anaerobic digestion process at thermophilic conditions.
\end{abstract}

Keywords: duckweeds, digestate, anaerobic digestion, biogas

\section{INTRODUCTION}

Duckweed are small free-floating plants in the flowering class, from the Cowhide family (Lemnaceae) (Xu et al., 2012), 37 different species of which were described worldwide, all belonging to five different genera, as quoted by Sree et al. (2016). In the Republic of Croatia, four species are common, Lemna, Spirodela, Wolffia, Wolfiella, while the fifth one is Landolita. All are characterized by a simple build, small leaf size $(3-15 \mathrm{~mm})$ of one or more, only a few layers of cell thickness, with or without visible roots. They use either vegetative or sexual reproduction. During the favourable conditions, they use vegetative reproduction division, which can double every 16 to 48 hours (FA0, 1999), which is 28 times more compared to corn, as quoted by Xiao et al. (2013). They spread to new habitats on the feet of pond birds and other animals and carried by water stream. The higher energy demands and the climate changes, which have been evident these past twenty years, have started a series of social and political changes that enabled the development and expanding of the technologies for utilizing renewable energy sources. To ease the competition between agricultural production for food and energetics, alongside traditional agricultural cultures customized for cultivation for energy needs, specific cultures, specialized only for energy needs, are beginning to emerge more and more. They are usually adapted to cultivation on surfaces which are not of a

(1) Damir Matošević, Mag. Eng. (damirmatosevic@vibrobeton.net), Vibrobeton d.o.o., Vječeslava Holjevca 20b, 10450 Jastrebarsko, Croatia (2) Prof. Dr. Davor Kralik, Prof. Dr. Irena Rapčan, Daria Jovičić, Mag. Eng. - Josip Juraj Strossmayer University of Osijek, Faculty of Agrobiotechnical Sciences Osijek, Vladimira Preloga 1, 31000 Osijek, Croatia 
high enough quality for the traditional agriculture, as described by Debovski et al. (2013). Plants from the duckweed family will in the future occupy an even more significant place, due to not competing with traditional agricultural crops in food production, and because for their own growth, they do not require soil. Due to that, the studies of duckweed as livestock feed were conducted (Muradov et al., 2012; AbdelRaouf et al, 2012). An added worthwhile advantage of duckweed is their ability to absorb large amounts of chemical elements and compounds and their tolerance of a high concentration of the aforementioned in the water solution on which they are cultivated. This can help with purifying wastewater of biogas power plants that appear as a byproduct of anaerobic digestion (Abuaku et al., 2006). However, the ability of accumulation of specific elements can as well be an inhibitory factor in the process of anaerobic digestion, as indicated by Jain et al (1992). Anaerobic digestion is a biochemical process in which the complex organic compounds are being degraded under the influence of different species of bacteria in anaerobic conditions as described by Cavinato et al. (2010). Panjičko (2015) states that in biogas plants the process results are biogas and digestate. Biogas is an environmentally acceptable, clean, cheap and versatile fuel that primarily consists of methane and carbon dioxide (Balat, 2008). Digestate is a processed residue of biogas manufacture. The process of emergence of biogas is a result of a series of connected process steps during which the initial substrate is degraded to simpler compounds, until it reaches biogas. The aim of this study is to determine the possibility of continuous cultivation of big duckweed on a digestate-based nutrient base, and to establish the influence of various concentrations of digestate in a nutrient solution on the quantity and quality of biogas, while taking into account the share of methane produced by anaerobic digestion of green mass of the harvested duckweed.

The experimental part of the research was conducted in two parts. The first part was the cultivation of duckweed in various concentrations of nutrient solution based on digestate. Big duckweed (Spirodela polyhiza) (Figure 1.) is a species also known as common duckmeat, and it belongs in the Lemnaceae family, as quoted by Sree et al. (2016). It can be found in nearly all areas of the world in many kinds of freshwater environments. It is a perennial water plant that usually grows in thick colonies and forms a dense structure on the surface of the water. Its leaf is smooth, round or oval-shaped, 5-10 $\mathrm{mm}$ in diameter, with the top of light or dark green colour and the bottom of a slightly reddish colour. Several small roots are visible at the bottom of the leaf. The plant produces shoots that carry both male and female flowers. The leaf part of the plant dies in autumn, and the part of the plant in the shape of the bud sinks to the bottom where it spends the winter, as described by Lemon et al. (2001). The buds (frond) that will spend the winter, as in the case of other species of duckweed, have the ability to form cells rich in starch of high specific weight in colder conditions, which allows them to sink to the bottom. Some studies have shown that the starch part of these plants is higher than $60 \%$. This species of duckweed has shown itself as the ideal raw material for the production of biogas due to its ability of fast growth in direct contact with nutritious mediums, as determined by Cui and Cheng (2014).

\section{MATERIAL AND METHODS}

In the current study, Spirodela polyhiza was cultivated in three lines, each of different concentration of nutrients, in controlled laboratory conditions with artificial lighting. Only healthy plants of characteristic colour and shape collected upstream of Vinkovci at the mouth of the Nevkoš creek into the Bosut River were used for cultivation.

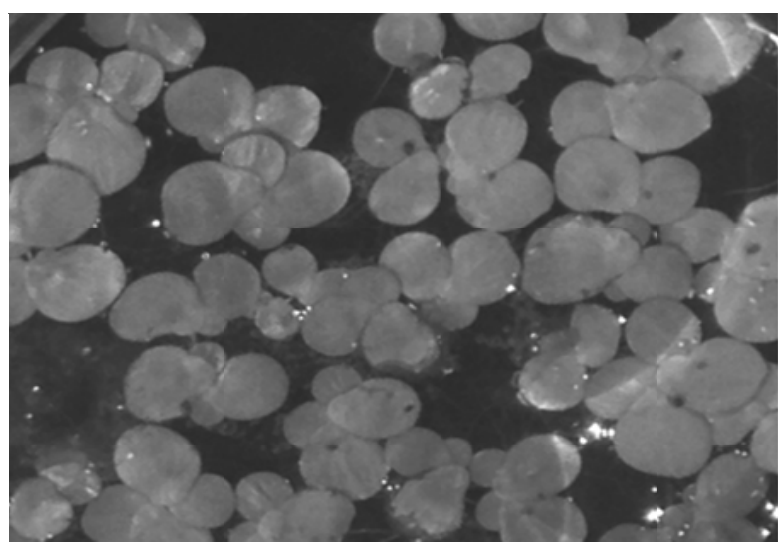

Figure 1. Duckweed (Spirodela polyrhiza)

Slika 1. Velika vodena leća (Spirodela polyrhiza)

(Source: own photo, 2017.)

Each cultivation line was set into five cascading pools of 14 litres, with the temperature regulation of nutrients solution and continuous artificially made circulation. Each pool was divided by surface PVC partitions that allowed for free circulation of nutrient solution and formed three equal cultivation units with the surface of $200 \mathrm{~cm}^{2}$ (K1-1, K1-2, K1-3, K2-1 etc., where the concentrations were SP $80 \sim 5.71 \%$, SP $60 \sim 4.29 \%$, SP $40 \sim 2.86 \%$. Growing conditions are shown in Table 1. The circulation was established with the aid of three pool circulation pumps, each with the power of $50 \mathrm{~W}$ and a muffled capacity vent for flow of about 5 litres per minute. The lighting used 13 "Sylvania Grolux" T5 neon lamps with the power of $54 \mathrm{~W}$ (702 W together) (Figure 2.). The lamp spectrum was adapted for the cultivation of water plants, and lamps were equipped with suitable shading of high shine and an hour mechanism for the simulation of natural lighting in the regime of 14 hours of light. The intensity of light varied between 15 to 33 kilo lux depending on the distance of the pools from the lamps. The experiment was conducted in a darkened air-conditioned room with minimal outside influences. 
Table 1. Growing conditions

Tablica 1. Uvjeti uzgoja

\begin{tabular}{|c|c|c|c|c|c|c|c|c|}
\hline \multicolumn{2}{|c|}{$\begin{array}{c}\text { SP } 80 \text { (5.71\%) growing conditions } \\
\text { Uvjeti uzgoja SP 80 (5,71\%) }\end{array}$} & \multicolumn{2}{c|}{$\begin{array}{c}\text { SP 60 (4.29\%) growing conditions } \\
\text { Uvjeti uzgoja SP 60 (4,29\%) }\end{array}$} & \multicolumn{3}{c|}{$\begin{array}{c}\text { SP 40 (2.86\%) growing conditions } \\
\text { Uvjeti uzgoja SP 40 (2,86\%o) }\end{array}$} \\
\hline K1-1 & K1-2 & K1-3 & K2-1 & K2-2 & K2-3 & K3-1 & K3-2 & K3-3 \\
\hline K1-1 & K1-2 & K1-3 & K2-1 & K2-2 & K2-3 & K3-1 & K3-2 & K3-3 \\
\hline K1-1 & K1-2 & K1-3 & K2-1 & K2-2 & K2-3 & K3-1 & K3-2 & K3-3 \\
\hline K1-1 & K1-2 & K1-3 & K2-1 & K2-2 & K2-3 & K3-1 & K3-2 & K3-3 \\
\hline K1-1 & K1-2 & K1-3 & K2-1 & K2-2 & K2-3 & K3-1 & K3-2 & K3-3 \\
\hline
\end{tabular}

$\mathrm{K} 1-1, \mathrm{~K} 1-2, \mathrm{~K} 1-3=$ digestate concentration of $5,71 \%$, K1-1, K1-2, K1-3 = koncentracija digestata od 5,71\%o $\mathrm{K} 2-1, \mathrm{~K} 2-2, \mathrm{~K} 2-3=$ digestate concentration of 4,29\%, K2-1, K2-2, K2-3 = koncentracija digestata od 4,29\%o $\mathrm{K} 3-1, \mathrm{~K} 3-2, \mathrm{~K} 3-3=$ digestate concentration of 2,86\%, K3-1, K3-2, K3-3 = koncentracija digestata od 2,86\%o

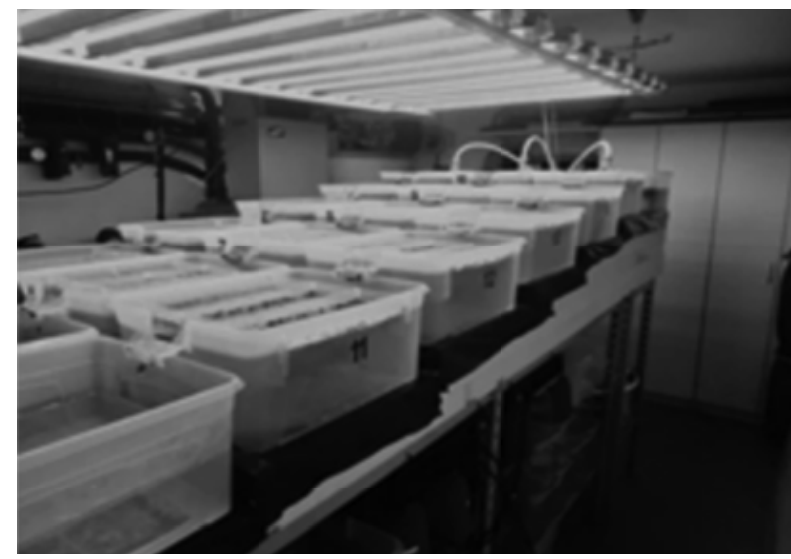

Figure 2. Lighting with Grolux lamps

Slika 2. Osvjetljenje pomoću Grolux lampi

The liquid phase of digestate was acquired from biogas plant Ovčara near Vukovar and was sieved additionally with a sieve of $0.5 \mathrm{~mm}$, so as to extricate the remaining parts of solid phase of digestate. Digestate would be analysed for the following characteristics: $\mathrm{pH}$ value using $\mathrm{pH}$ meter Metrohm; the dry matter content would be determined gravimetrically by drying the samples at $105^{\circ} \mathrm{C}$ in a Memmert UFE 600 laboratory oven; the content of organic matter and ash would be determined by annealing the dry samples in a muffle furnace at $550^{\circ} \mathrm{C}$ to constant mass; and the total nitrogen content would be determined by the Kjeldahl method. The duckweed cultivation lasted 30 days. The starting amount of plants was $20 \mathrm{~g}$ in a pool, and the harvest of duckweed was conducted in the period of five days in the moment of complete pool surface coverage with duckweed. Figure 3 shows the layout of the experiment.

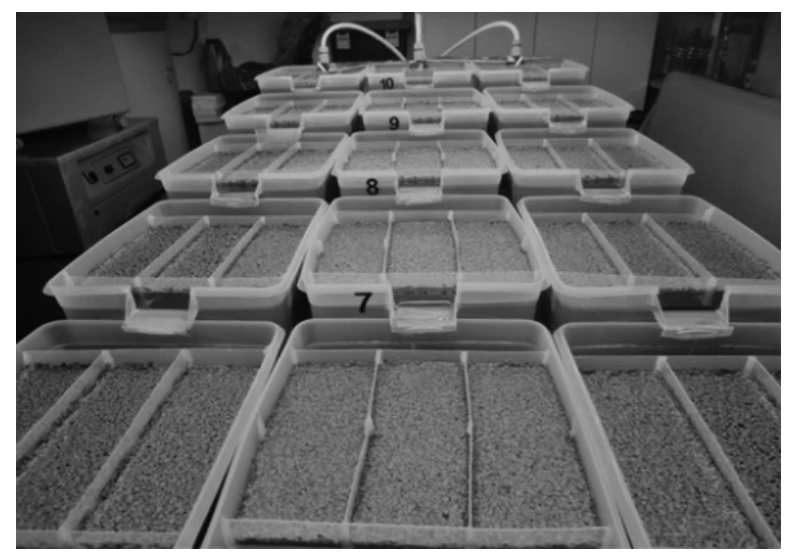

Figure 3. Layout of the experiment

Slika 3. Postav pokusa

(Source: own photo, 2017.)

The second part of the study consisted of anaerobic digestion conducted in a laboratory. The green mass of cultivated duckweed was collected, frozen and used as raw material in the production of biogas in the process of anaerobic digestion in discontinued reactors of 1 litre volume at thermophilic conditions and the hydraulic retention time (HRT) of 30 days. In discontinuous reactors, HRT represents the duration of fermentation. The planned HRT in this experiment was 30 days or until the day when the daily biogas production drops to less than $1 \%$ of the total amount of biogas produced by then. Figure 4 shows the schematic batch process of anaerobic digestion. Three groups were formed with different sample concentration of digestate (SP 80, SP 60 and SP 40), which consisted of fresh bovine manure mixed with a $5 \%$ part of cultivated duckweed and of a control group of fresh bovine manure on its own. All three samples and one control group were set in three repetitions. Fermentation was tracked daily and the produced biogas was collected into calibrated measuring vessels, which were connected to the reactor by a flexible transparent hose. The chemical compound of biogas (part of $\mathrm{CH}_{4}$ ) was processed by gas chromatograph Varian 3900 using a modified method (HRN ISO 6974-4:2001). 


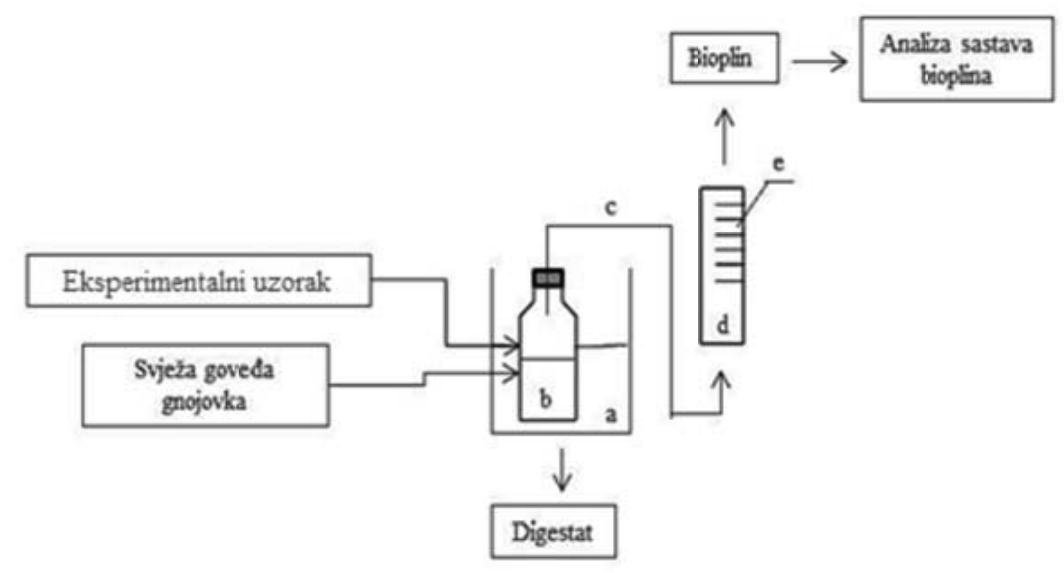

Figure 4. Schematic display of anaerobic digestion batch process: a) thermostated water bath, b) reactor bottle, c) rubber tube, d) diluted NaCl solution, e) measuring beaker for biogas gathering

Slika 4. Shematski prikaz provedbe šaržnog procesa anaerobne digestacije: a) termostatirana vodena kupelj, b) reaktorska boca, c) gumena cijev, d) prezasićena otopina $\mathrm{NaCl}$ e) menzura za prikupljanje bioplina

(Source: adapted by Kovačić (2017.))

\section{RESULTS AND DISCUSSION}

The difference in green mass of big duckweed (Spirodela polyrhiza) is visible in the cumulative display by days of the experiment (Graph 1). The digestate used to grow the aqueous lens before the experiment was analysed for the characteristics shown in Table 2.

Table 2. Results of digestate analysis

Tablica 2. Rezultati analize digestata

\begin{tabular}{|c|c|c|c|c|}
\hline $\begin{array}{c}\mathrm{pH} \\
\mathrm{pH}\end{array}$ & $\begin{array}{c}\text { Dry matter (\%) } \\
\text { Suha tvar (\%) }\end{array}$ & $\begin{array}{c}\text { Organic matter (\%) } \\
\text { Organska tvar (\%) }\end{array}$ & $\begin{array}{c}\text { Organic carbon (\%) } \\
\text { Organski ugljik (\%) }\end{array}$ & $\begin{array}{c}\text { Total nitrogen (\%) } \\
\text { Ukupni dušik (\%) }\end{array}$ \\
\hline 8.13 & 8.95 & 72.88 & 38.00 & 0.516 \\
\hline
\end{tabular}

In the initial phase of the duckweed growth, the differences in the growth of green mass were less visible, while in the second part of the experiment, the difference was shifted to the benefit of nutrient richer solutions. Almost linear cumulative display of green mass cultivation indicates the constant growth and the possibility of continuous cultivation of duckweed, due to the plants being of the same colour and the same general condition of the plant community during the entire experiment.
In the observed period of 30 days, $658 \mathrm{~g}$ of green mass of the plant was cultivated on the nutrient solution with digestate concentration of $80 \mathrm{ml}$ per 14 I (SP 80), $607 \mathrm{~g}$ was cultivated on the concentration of $60 \mathrm{ml}$ per 14 I (SP 60), and on the concentration of $40 \mathrm{ml}$ per 14 I (SP 40), $569 \mathrm{~g}$ of green mass was cultivated (Graph 2). By increasing the concentration of nutrient solution, the green mass of plants is increased as much as $6.68 \%$ (SP 60) and $15.64 \%$ (SP 80).

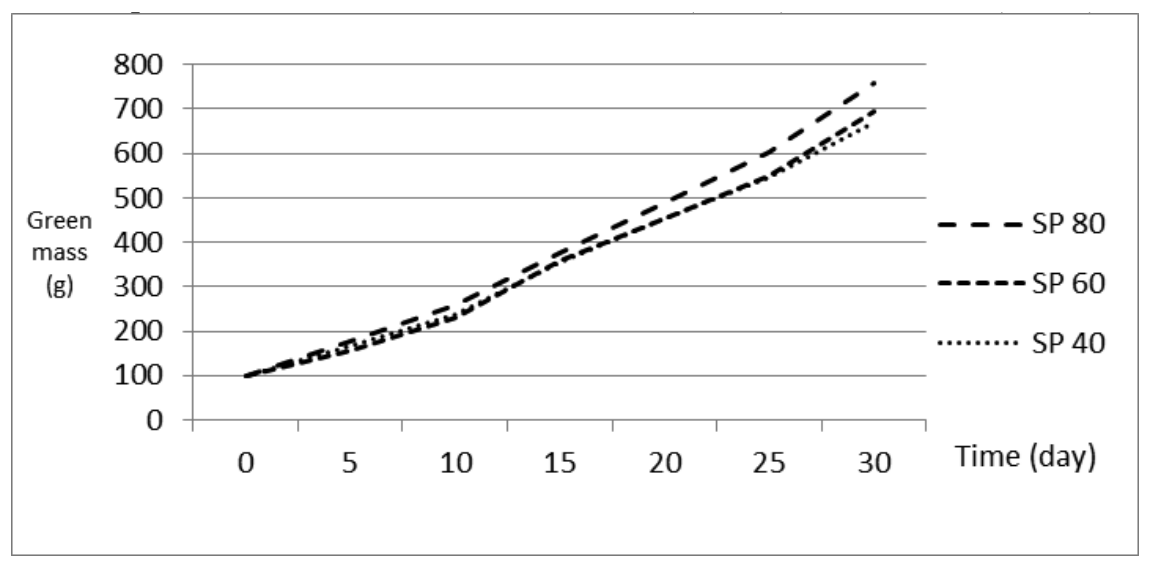

Graph 1. The cumulative growth of duckweed green mass by days of the experiment $(\mathbf{g})$

Grafikon 1. Kumulativni prikaz prirasta zelene mase vodene leće po danima pokusa (g) 
Recalculating these values to hectare as the surface unit, the values which represent the amounts of fresh green mass of duckweed are as follows: 329 , 303.5 and $284.5 \mathrm{t} \mathrm{ha}^{-1}$ month $^{-1}$ with digestate concentrations of SP 80, SP 60 and SP 40. In the experiments with different species of duckweed (Lemmna gibba), Oron (1994) had the yearly yield of dry matter of around $55 \mathrm{t} \mathrm{ha}^{-1}$. Xu et al. (2012) compared the dry biomass of duckweeds and different species of plants and found that duckweed produced around 39.1-105.9 $\mathrm{t} \mathrm{ha}^{-1}$ yearly, which is nearly in the range of algae (90.3-175.2 $\mathrm{t} \mathrm{ha}^{-1}$ year $^{-1}$ ) and far more than some other species.

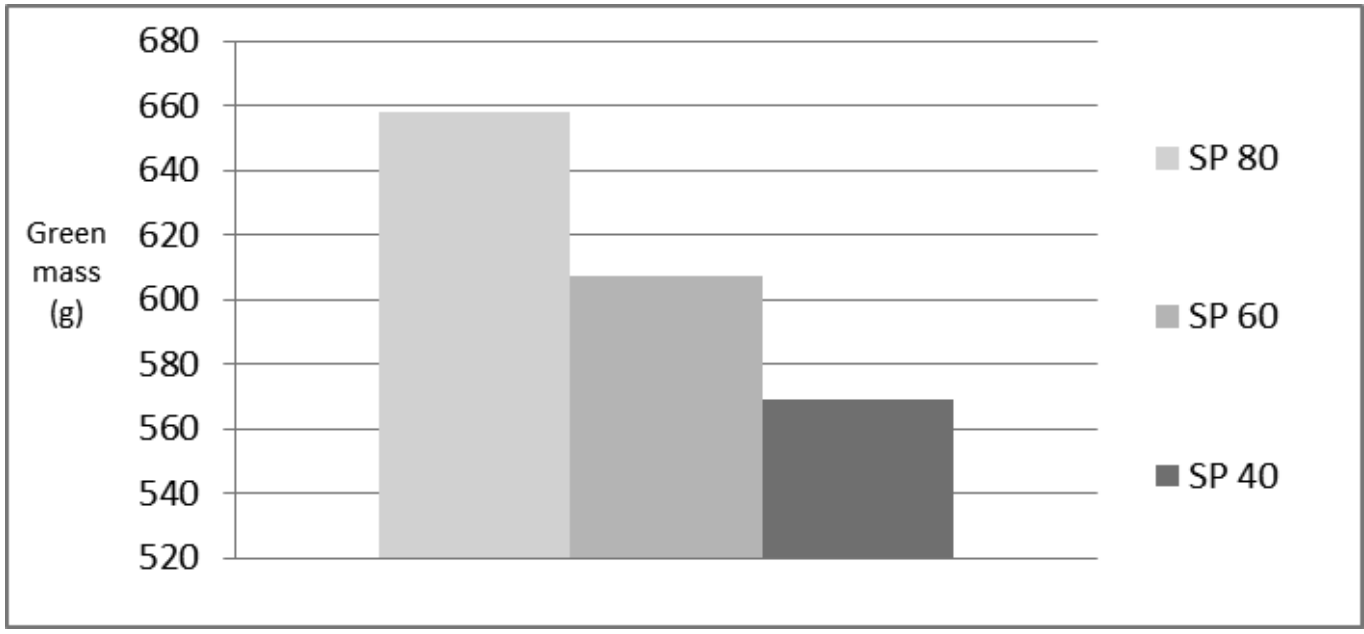

Graph 2. Yield of duckweed green mass (g per $\left.200 \mathbf{c m}^{2}\right)$

Grafikon 2. Prinos zelene mase vodene leće $\left(\mathrm{g} / 200 \mathrm{~cm}^{2}\right)$

In the next phase of the research, the obtained green mass of duckweed was subjected to the procedure of anaerobic digestion. The accomplished yield of biogas is shown in Graph 3, which shows the cumulative display of biogas production in the experimental period. In the displayed graph, it can be seen that the yield of biogas was greatest in the first week, after which it slows and is kept at nearly the same values.

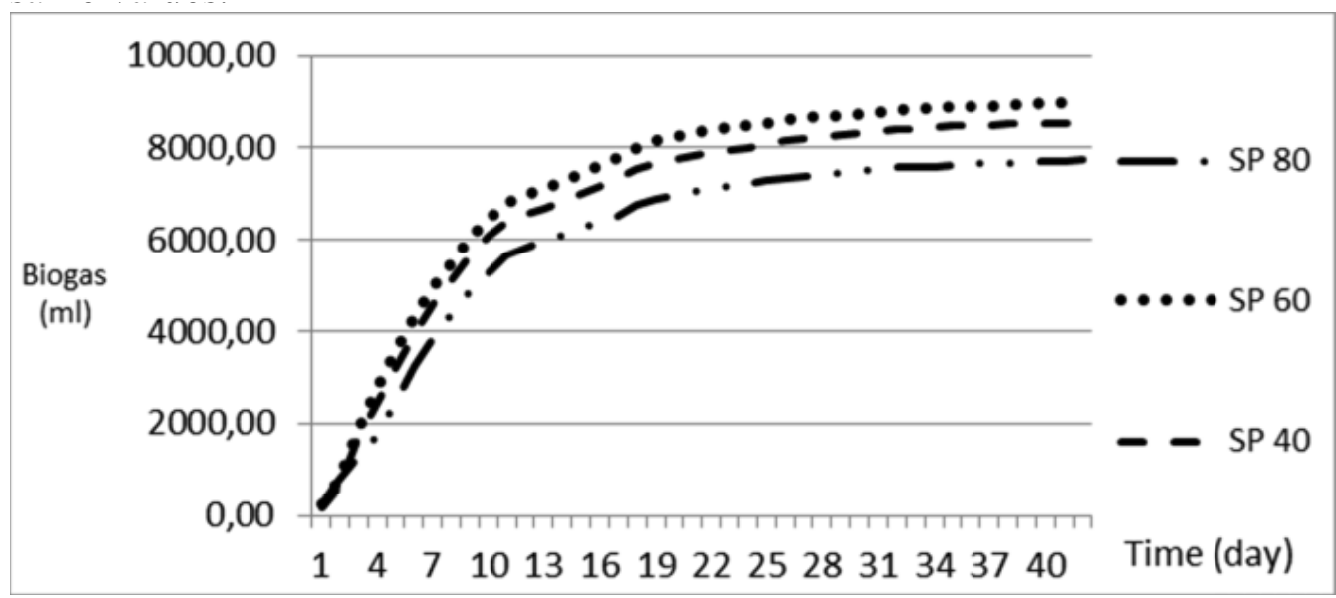

Graph 3. Cumulative biogas production by days of the experiment (ml)

Grafikon 3. Kumulativna proizvodnja bioplina po danima pokusa (ml)

The green mass of duckweed cultivated on SP 60 concentration gave the highest yield of biogas $(48368.80 \mathrm{ml})$, while the green mass cultivated on the concentration SP 80 gave the lowest yield of biogas (19664.33 $\mathrm{ml}$ ), and the concentration (SP 40) gave the mean yield (35610.87 $\mathrm{ml}$ ), as seen in Graph 4 . 


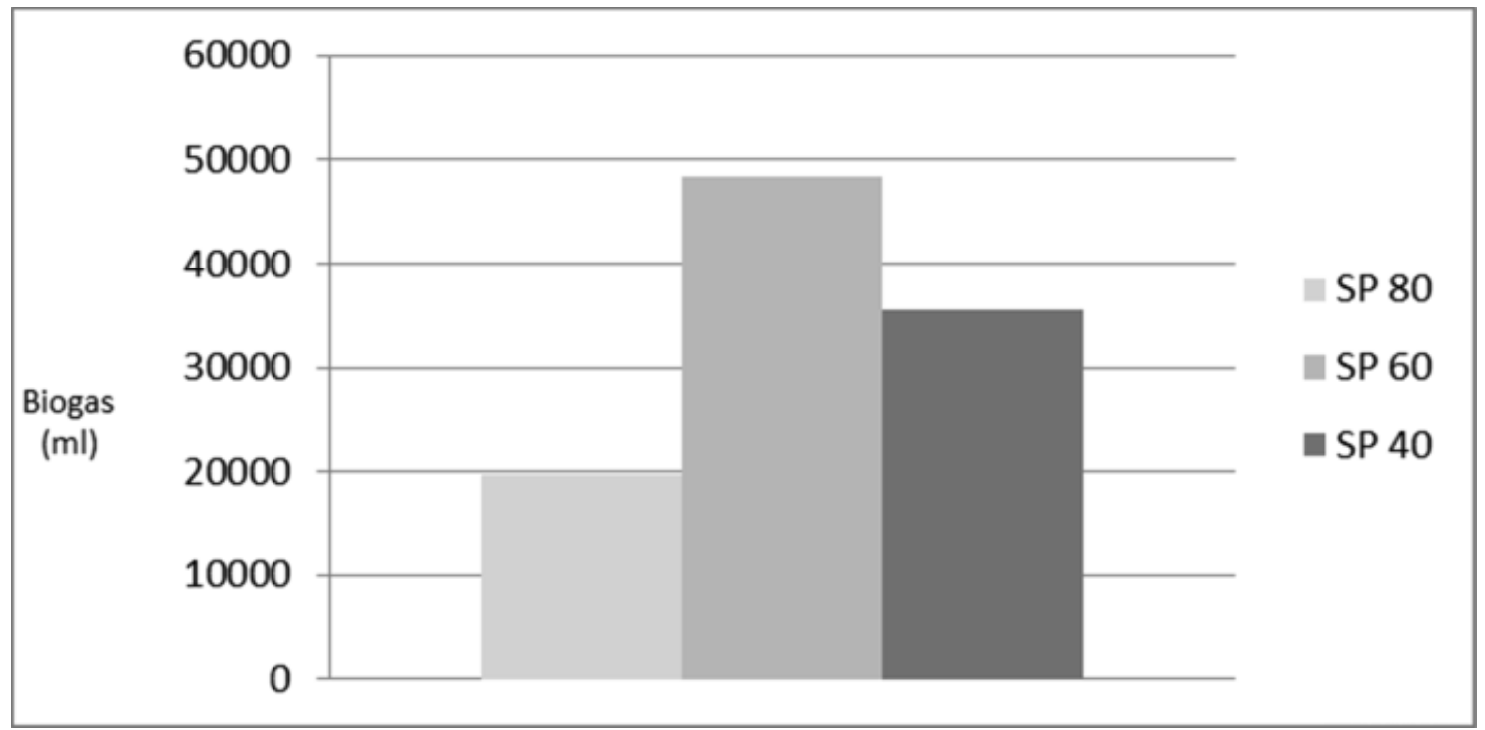

Graph 4. Biogas yield (ml)

Grafikon 4. Prinos bioplina (ml)

Expressing these values in cubic meters per hectare per month, the values are as follows: $17805.44 \mathrm{~m}^{3}$ $\mathrm{ha}^{-1}$ (SP 80), 24184.40 $\mathrm{m}^{3} \mathrm{ha}^{-1}$ (SP 60) and $9832.17 \mathrm{~m}^{3}$ $\mathrm{ha}^{-1}$ (SP 40). The limiting factor in biogas production is also the temperature of the process. This experiment was done under thermophilic conditions, used in commercial biogas installations, which were used as basic raw material for corn silage. However, it is well known that mesophilic conditions are more favourable for the digestion of duckweeds biomass, as established by Ramaraj and Unpapro in their research (2016). After their own research, Calicioglu and Brennan (2018) concluded that significant methane production is pos- sible from the biomass of water lenses. The methane yield (CH4), which is the most important determinant of biogas quality, was low in the initial phase of this experiment, and after 2-3 days of digestion, it was growing rapidly and remained high at the end of the process (Graph 5). Biomass of water lenses obtained on digestates of different concentrations results in different yields of methane. The highest yield of methane in biogas was achieved in the SP 60 (24765.32 ml) sample, while the lowest was obtained in sample SP 80 $(11033.50 \mathrm{ml})$, while the concentration of digestate SP 40 was meta-methane yield $(19834.60 \mathrm{ml})$, as visible from Graph 6.

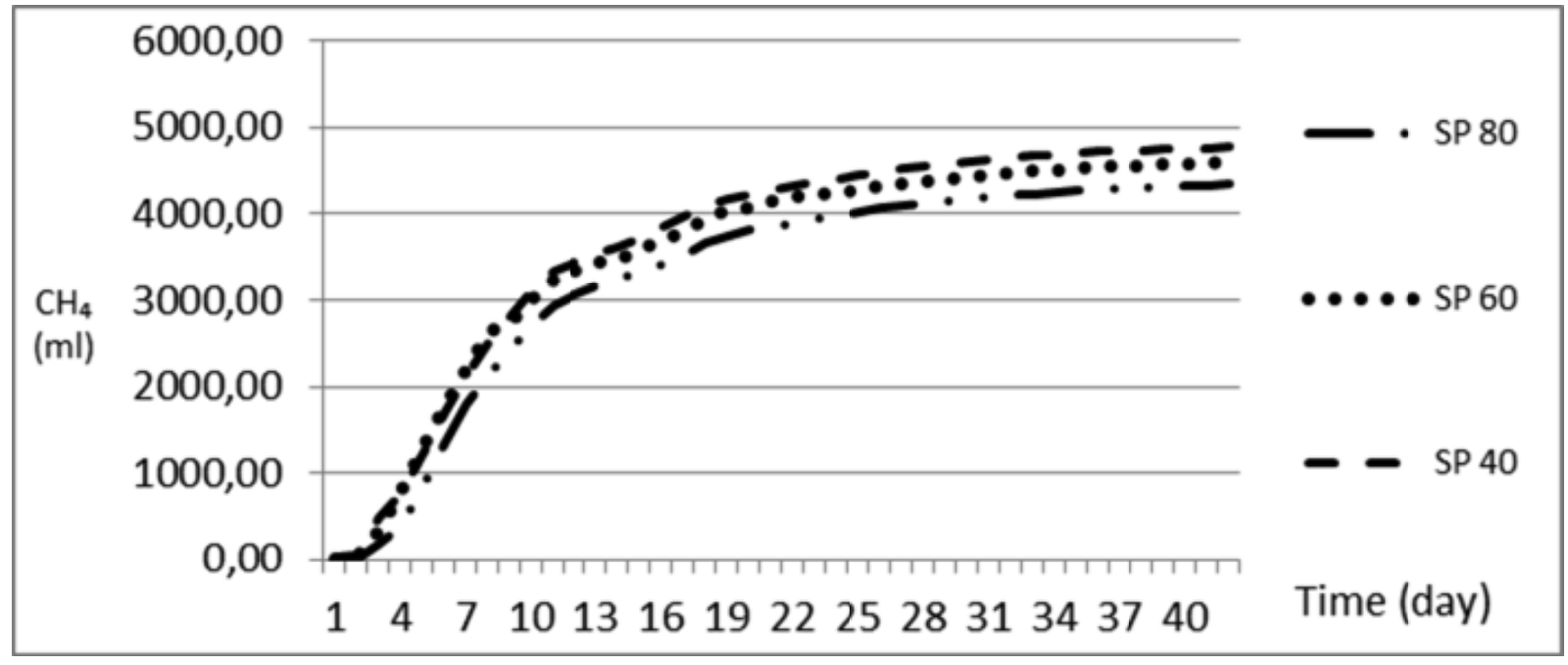

Graph 5. Cumulative production of $\mathrm{CH}_{4}$ by days of the experiment (ml)

Grafikon 5. Kumulativni prikaz proizvodnje $\mathrm{CH}_{4}$ po danima pokusa (mI) 


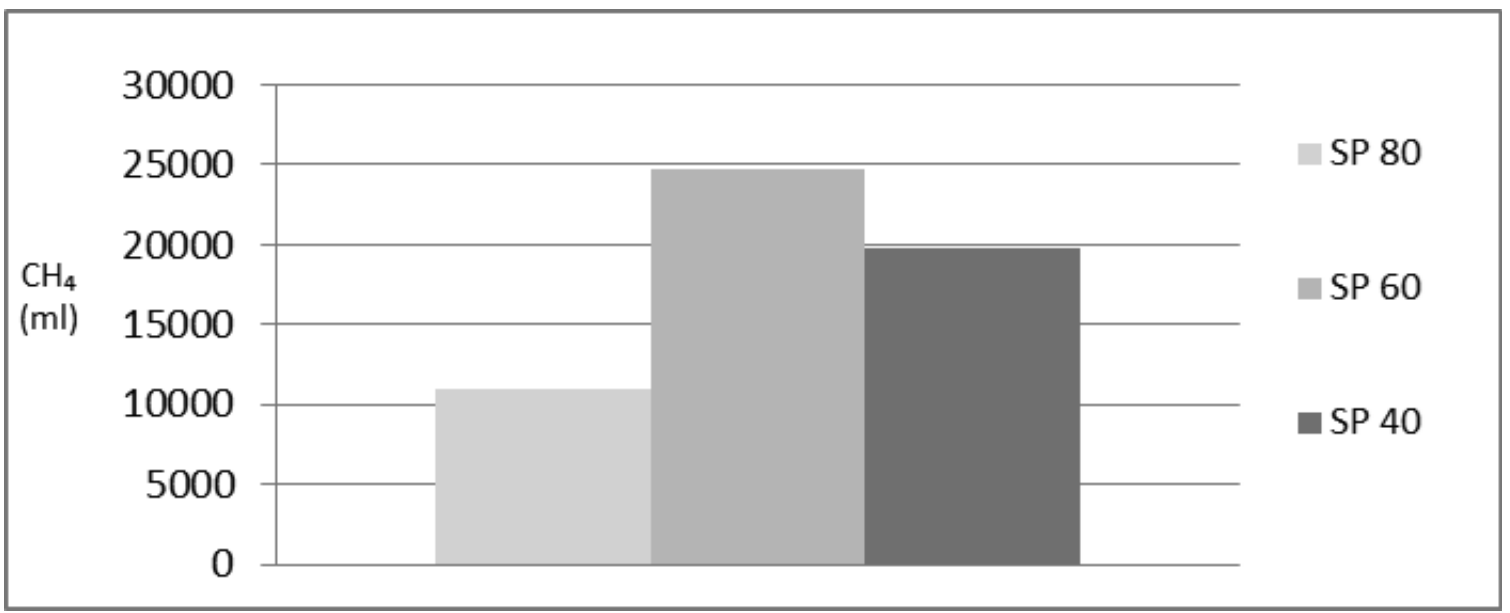

Graph 6. Methane yield (ml)

Grafikon 6. Prinos metana (ml)

When these values are expressed in $\mathrm{m}^{3} \mathrm{ha}^{-1}$ month $^{-1}$ units then the values appear as follows: $5516.75 \mathrm{~m}^{3} \mathrm{ha}^{-1}$ (SP 80), $12382.66 \mathrm{~m}^{3} \mathrm{ha}^{-1}$ (SP 60) and $9917.30 \mathrm{~m}^{3} \mathrm{ha}^{-1}$ (SP 40). It is interesting to note that the biomass of water lenses grown at the highest concentration of digestate yields the smallest yield of methane, which may mean that the growth of water lenses is more suitable for digestates of lower concentrations. This is probably the result of less protein, and larger carbohydrates in plants grown at lower concentrations of digestate. Lower yields of methane and its share in biogas $(57.61 \%)$ are obtained by Kovačić et al. (2014), while in our study the methane content was as follows for SP 80 , SP 60 and SP $40: 56 \%, 51 \%$ and $56 \%$. By comparing several types of water lenses, Toyama et al. (2018) find that Spirodela polyrhiza shows a higher rate of biomass production, greater nitrogen removal and a potential of higher methane production than other species.

\section{CONCLUSION}

The cultivation of duckweed in the nutrient solution based on digestate with the aim of production of biogas can be conducted continuously, no matter the high variation in the growth speed and green mass yield due to the vegetative cycle of growth and the high maintenance of optimal conditions for the growth of duckweed. Increasing the concentration of the nutrient-solution digestate effects in a higher green mass of duckweed. In the described experiment, the yield of green mass increased on average by $7.6 \%$ for each additional $50 \%$ increase in the concentration of digestate in the nutrient solution. However, in case of biogas or methane production, increasing the digestate concentration to more than $4.29 \%(60 \mathrm{ml} / 14 \mathrm{l})$ in the nutrient solution can be counterproductive.

From these results, after the process of anaerobic digestion, the dependence of biogas and methane yield on the applied concentration of digestate in the nutrient solution can be observed. In this case, increasing the digestate concentration above $60 \mathrm{ml}$ per $14 \mathrm{I}$ adversely affects biogas and methane yields. The decrease in methane yield is greater than the increase in green mass yield.

Due to the prevalence of duckweed species in Croatia and their capabilities (wastewater treatment, biogas production), it can be concluded that these plants are a very acceptable resource, but that additional research is needed in these areas.

\section{REFERENCES}

1. Abdel-Raouf, N., Al-Homaidan, A. A., \& Ibraheem, I. B. M. (2012). Microalgae and waster water treatment. Saudi Journal of Biological Sciences, 19, 257-275. https://doi.org/10.1016/j.sjbs.2012.04.005

2. Abuaku, E., Frimpong, K.A., Osei, B.A., \& Vestraete, W. (2006). Bio-Recovery of $N$ and $P$ from an Anaerobic Digester Effluent: The Potential of Duckweed. West African Journal of Applied Ecology, 10(1), 153-162. https://doi.org/10.4314/wajae.v10i1.45711

3. Balat, M. (2008). Progress in biogas production processes. Energy, Education, Science and Technology, 22(1), 15-36.

4. Cavinato, C., Fatone, F., Bolzonella D., \& Pavan, P. (2010). Thermophilic anaerobic co-digestion of cattle manure with agro-wastes and energy crops: Comparison of pilot and full scale experiences. Bioresource Technology, 101(2), 545-550.

https://doi.org/10.1016/j.biortech.2009.08.043

5. Cui, W., \& Cheng, J.J. (2014). Growing duckweed for biofuel production. Plant Biology, 17(1), 16-23. https://doi.org/10.1111/plb.12216

6. Debovski, M., Zelinski, M., Grala, A., \& Dudek, M. (2013). Alge biomass as an alternative substrate in biogas production technologies - Review. Reneeable and Sustainable Energy Reviews, 27, 596-604. https://doi.org/10.1016/j.rser.2013.07.029 
7. Food and Agricultural Organization (1999). Duckweed: $A$ tiny aquatic plant with enormous potential for agriculture and environment. Retrieved from http://www.fao.org/ag/ AGAinfo/resources/documents/DW/Dw2.htm

8. EN13654-1: Determination of Kjeldahl Nitrogen in soil, biowaste and sewage sludge.

9. Hrvatskizavod za norme (2008). Prirodni plin - Određivanje sastava s određenom nesigurnošću plinskom kromotografijom - 4. dio: Određivanje dušika, ugljikovog dioksida i C1 do C5 i C6 + ugljikovodika u labotarorijskom sastavu i on line mjernom sustavu uporabom dviju kolona (ISO 6974-4:2000). Preuzeto s http://31.45.242.218/HZN/ Todb.nsf/wFrameset2

10. International standard, Water quality - Determination of selected elements by inductively coupled plasma optical emission spectrometry ISO 11885

11. Jain, S. K., Gujral, G. S., Jha, N. K., \& Vasudevan, P. (1992). Production of biogas from Azolla pinnata $R$. and Lemna minor L.: Effect of heavy metal contamination. Bioresource Technology, 41(3), 273-277. https://doi.org/10.1016/0960-8524(92)90013-N

12. Kovačić, Đ. (2017). Razvoj procesa predobrade lignoceluloznih materijala toplinom i električnim poljem u svrhu primjene u proizvodnji bioplina anaerobnom kodigestijom s goveđom gnojovkom, doktorska disertacija, Sveučilište J.J. Strossmayera u Osijeku I Institut Ruđer Bošković, Osijek.

13. Kovačić, Đ., Kralik, D., Matošević, D., Jovičić, D. (2014). Mogučnosti korištenja biomase vodene leće (lemna minor) u proizvodnji bioplina. Krmiva 56:57-62, URI https//hrcak/139635
14. Lemon, G. D., Posluszny, U., \& Husband, B.C. (2001). Potential and realized rates of vegetative reproduction in Spirodela polyrhiza, Lemna minor, and Wolffia borealis. Aquatic Botany, 70(1), 79-87. https://doi.org/10.1016/S0304-3770(00)00131-5

15. Muradov, N., Fidalgo, B., Gujar, A. C., Garceau, N., \& T-Raissi, A. (2012). Production and characterization of Lemna minor bio-char and its catalytic application for biogas reforming. Biomass and Bioenergy, 42, 123-131. https://doi.org/10.1016/j.biombioe.2012.03.003

16. Panjičko, M. (2015), Razvoj procesa proizvodnje bioplina anaerobnom digestijom pivske komine kao monosupstrata. Doktorska disertacija. Fakultet kemijskog inženjerstva i tehnologije, Zagreb.

17. Ramaraj, R., \& Unpaprom, Y. (2016.). Effect of temperature on the performance of biogas production from Duckweed. Chemistry Research Journal, 1(1), 58-66.

18. Sree, K. S., Bog, M., \& Appenroth, K. J. (2016). Taxonomy of duckweeds (Lemnaceae), potential new crop plants. Emirates Journal of Food and Agriculture, 28(5), 291-302. https://doi.org/10.9755/ejfa.2016-01-038

19. Xiao, Y., Fang, Y., Zhang, G., \& Zhao, H. (2013.). Culturing duckweed in the field for starch accumulation. Industrial Crops and Products, 48, 183-190. https://doi.org/10.1016/j.indcrop.2013.04.017

20. Xu, J., Zhao, H., Stomp, A. M., \& Cheng, J. J. (2012.): The production of duckweed as a source of biofuels. Biofuels 3(5), 589-601. https://doi.org/10.4155/bfs.12.31

\section{UTJECAJ KONCENTRACIJE DIGESTATA PRILIKOM UZGOJA NA KVALITETU BIOPLINA DOBIVENOGA ANAEROBNOM DIGESTACIJOM VODENE LEĆE (Spirodela polyrhiza)}

\section{SAŽETAK}

Vodena leća je široko rasprostranjena vrsta sitnih slobodno plivajućih biljaka iz razreda cvjetnica. Tipičan predstavnik porodice kozlačevki (Lemnaceae) je velika vodena leća (Spirodela polyrhiza) i vrlo je česta na vodenim površinama kontinentalne Hrvatske. Kao i sve ostale vrste vodenih leća, karakterizira ju mogućnost vegetativnoga i spolnog razmnožavanja te vrlo brz rast. Smatra se vrlo poželjnom sirovinom za proizvodnju bioplina iz nekoliko razloga. Nužnost smanjenja zagađenja okoliša nitratima iz poljoprivredne proizvodnje te sposobnost rasta vodenih leća u eutrofnim uvjetima potaknuli su ovo istraživanje. Primarni cilj istraživanja jest utvrditi mogućnosti kontinuiranoga uzgoja velike vodene leće na različitim koncentracijama digestata, sa ciljem proizvodnje bioplina. Sekundarni je cilj utvrditi zavisnost između različitih koncentracija digestata korištenih za proizvodnju zelene mase vodene leće te kvantitete $i$ kvalitete bioplina dobivenog postupkom anaerobne digestije pri termofilnim uvjetima.

Ključne riječi: vodena leća, digestat, anaerobna digestija, bioplin

(Received on February 28, 2019; accepted on November 11, 2019 - Primljeno 28. veljače 2019.; prihvaćeno 11. studenoga 2019.) 